A Research Report for the Atlantic Richfield Hanford Company

\title{
Electrochemical Decontamination of Strontium Fluoride Storage Capsules
}

by

H. W. Arrowsmith

W. C. Budke

R. P. Allen

D. W. Jeppson

February 1977

Prepared for the U.S. Energy

Research and Development Administration

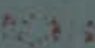


NOTICE

This report was prepared as an account of work sponsored by the United States Government. Neither the United States nor the Energy Research and Development Administration, nor any of their employees, nor any of their contractors, subcontractors, or their employees, makes any warranty, express or implied, or assumes any legai liability or responsibility for the accuracy, completeness or usefulness of any information, apparatus, product or process disclosed, or represents that its use would not intringe privately owned rights.

PACIFIC NORTHWEST LABORATORY

operated by

BATTELLE

for the

ENERGY RESEARCH AND DEVELOPMENT ADMINISTRATION

Under Contract EY-76-C-06-1830

Printed in the United States of America

Available from

National Technical Information Service

U.S. Department of Commerce

5285 Port Royal Road

Springfield, Virginia 22151

Price: Printed Copy \$__: Microfiche $\$ 3.00$

NTIS

- Pages Selling Price

$001-025 \quad \$ 4.50$

026-050 $\quad 55.00$

051-075 $\$ 5.50$

$076-100 \quad \$ 6.00$

$101.125 \quad \$ 6.50$

$126-150 \quad \$ 7.00$

$151-175 \quad \$ 7.75$

$176.200 \quad \$ 8.50$

$201-225 \quad \$ 8.75$

$226-250 \quad \$ 9.00$

$251-275 \quad 510.00$

276-300 $\quad 510.25$ 
BNWL -2125

UC -70

ELECTROCHEMICAL DECONTAMINATION OF

STRONTIUM FLUORIDE STORAGE CAPSULES $(a)$

by

H. W. Arrowsmith (b)

W. C. Budke (b)

R. P. Allen (b)

D. W. Jeppson (c)

February 1977

BATTELLE

Pacific Northwest Laboratories

Richland, Washington 99352

(a) This was performed as part of Atlantic Richfield Hanford Company's Encapsulation Equipment and Instrument Development Program, R. E. Felt, Program Coordinator. This work is supported by U.S. Energy Research and Development Administration under Contract E(45-1)-2130.

(b) Materials Department, Metallurgy Research Section

(c) Development Engineering Department, Separations Process Engineering Section, Atlantic Richfield Hanford Company 
-

$\bullet$

5

$:$ 


\section{SUMMARY}

Double containment in Hastelloy $\mathrm{C}-276$ capsules is used to ensure the safe, long-term storage of radioactive strontium fluoride processed through the Hanford 225-B encapsulation facility. The inner storage capsule (5.7-cm $0 . D$. by $0.484 \mathrm{~cm}$ long) is filled with strontium fluoride powder in a hot cell and sealed using remote gas tungsten arc welding. These remote filling, welding, and handling operations unavoidably contaminate the capsule surface with strontium fluoride in a form that is extremely difficult to remove using conventional scrubbing and spray decontamination procedures.

This report summarizes work conducted under Atlantic Richfield Hanford Company (ARHCO) sponsorship to develop electropolishing as an alternative surface decontamination technique for the inner storage capsule. Initial feasibility studies using contaminated dummy capsules and capsule sections demonstrated the ability of electropolishing to rapidly and effectively remove the external strontium fluoride contamination. For example, the radiation levels of capsule surfaces smearing $4 \mathrm{rad} / \mathrm{hr}$ were reduced to less than 200 counts/min by electropolishing for less than $30 \mathrm{~min}$. Based on these test results, a 20-l electropolishing system incorporating a cylindrical cathode to preserve capsule dimensions and special design features to facilitate remote manipulator operation was developed for installation in the B-plant encapsulation facility. With this electrochemical capsule decontamination system, it should be possible to produce the nonsmearable surface required for secondary encapsulation by electropolishing the capsules for less than 30 min with a total metal removal of less than $50 \mu \mathrm{m}$.

The following supporting studies also were conducted to establish optimum operating conditions and to test the capsule facility design concepts:

- Operating Parameter Studies - Phosphoric acid was selected as the electrolyte for the capsule decontamination work based on solution disposal considerations. The effects of electrolyte temperature, acid concentration, and dissolved metal content on electropolishing 
behavior and current density-voltage relationships for Hastelloy C-276 in phosphoric acid were determined. The limiting current density increased significantly with increasing temperature and decreased with increasing acid concentration and dissolved metal content. Based on the test results, the recommended operating parameters for capsule decontamination are:

Electrolyte composition - $75 \%$ phosphoric acid

Operating temperature -45 to $55^{\circ} \mathrm{C}$

Current density $\quad-17$ to $21 \mathrm{~A} / \mathrm{dm}^{2}$

- Solution Life Studies - Anode dissolution tests were conducted to determine the ultimate disposition of the metal removed from the electrode. $\mathrm{SrF}_{2}$ was added to the anode to simulate removal of contamination. The electrolyte dissolved more than $10 \mathrm{wt} \%$ metal without sludge formation. Above $6 \mathrm{wt} \%$ dissolved metal, about one-tenth of the adoitional metal removed plated out on the cathode. The electrodeposited material was primarily nickel, with lesser amounts of iron, co'salt, tungsten, and molybdenum. All of the chromium and strontium remained in solution. This suggests that solution life for the capsule decolitamination facility will be governed by the buildup of contamination in the electrolyte rather than by dissolved metal content limitations.

- Spectral Emittance Studies - Spectral emittance data were obtained for electropolished Hastelloy $\mathrm{C}-276$ specimens to ensure that the decontamination process would not seriously impair the heat transfer characteristics of the fission product storage capsules. No significant differences were found between the emittance of the as-received tubing $(E=0.22$ at $\lambda=1.6$ to $2.7 \mu \mathrm{m})$ and surfaces electropolished under various conditions to produce dull and bright surface finishes $(E=0.19$ to 0.26$)$.

- Capsule Profile Studies - Metal removal by the electropolishing process must be uniform to preserve capsule dimensions. The capsule decontamination facility was designed with a cylindrical cathode to promote 
uniform metal removal around the circumference of the capsule. Uniformity along the capsule was achieved by adjusting the cathode area, modifying the anode holder, and varying the operating conditions until the difference in the amount of metal removed at any two points along the capsule was less than $\pm 10 \%$ of the average change in wall thickness $(\sim 40 \mu \mathrm{m})$ for a normal decontamination treatment. 
. • 


\section{CONTENTS}

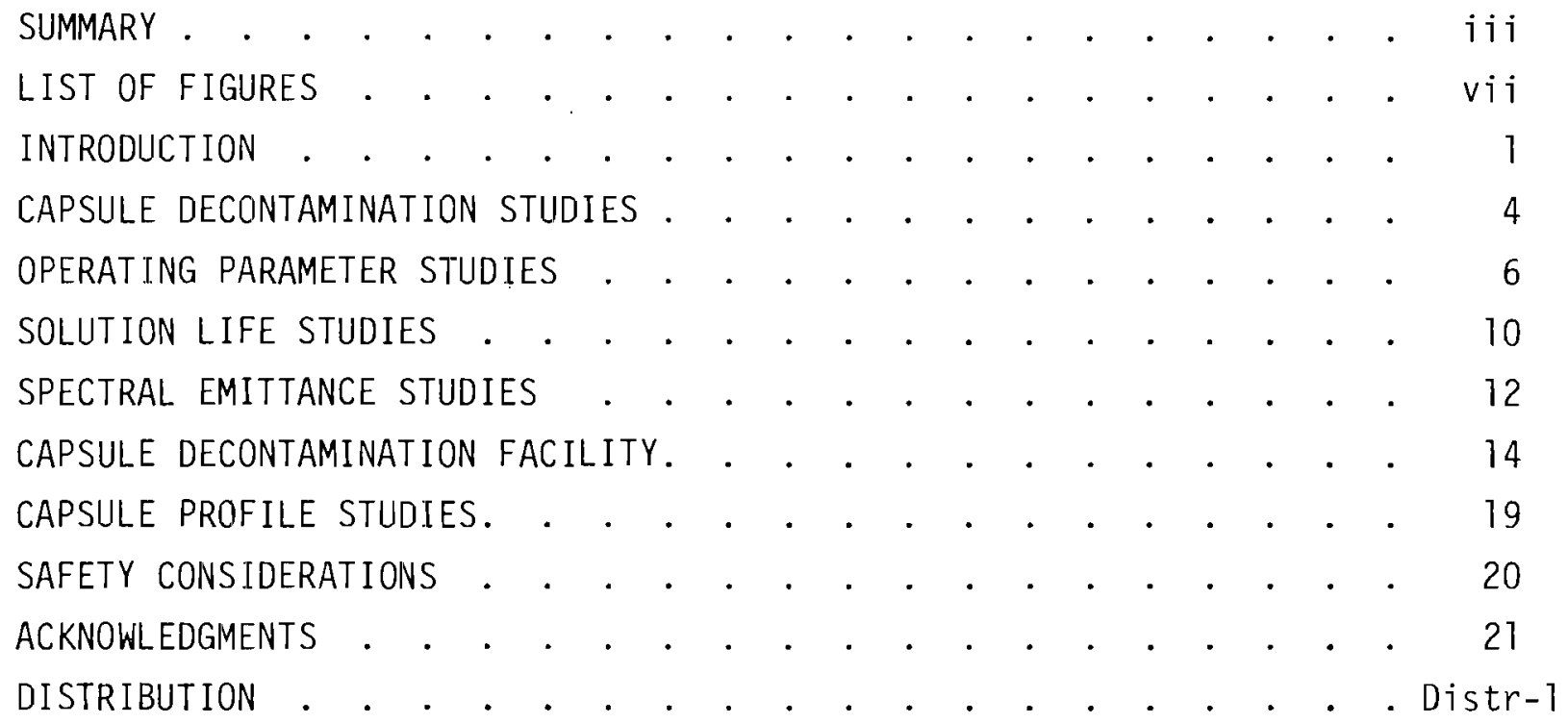




\section{LIST OF FIGURES}

1 Theory of Electrochemical Decontamination . . . . . . . . . 1

2 Surface Smoothing as a Function of Metal Removal for Electropolished Material . . . . . . . . . . . . . 2

3 Relationship of Current Density and Cell Voltage for Electropolishing Showing the Optimum Operating Region for Electrochemical Decontamination. . . . . . . . . . 3

4 Schematic Drawing of Electrolytic Cell used for Electrochemical Decontamination. . . . . . . . . . . . . . . 5

5 Effect of Temperature on Current Density Versus Cell Voltage Curves for Hastelloy C-276 in a 55\% Phosphoric Acid Electrolyte. . . . . . . . . . . . . . . . . 7

6 Effect of Electrolyte Concentration on Current Density Versus Cell Voltage Curves for Hastelloy C-276 in Phosphoric Acid at $25^{\circ} \mathrm{C}$. . . . . . . . . . . . . . . . 7

7 Effect of Dissolved Metal Content on Current Density Versus Cel1 Voltage Curves for Hastelloy C-276 in 55\% Phosphoric Acid at $25^{\circ} \mathrm{C}$. . . . . . . . . . . . . . . 8

8 Current Versus Ce11 Voltage Curves for Hastelloy C-276 and 316-L Stainless Steel Capsules Electropolished in the Capsule Decontamination Facility. . . . . . . . . . . ' 9

9 Electropolishing Cell Designed for the Remote Decontamination of Fission Product Storage Capsules. . . . . . 15

10 Cathode Assembly for the Remote Capsule Decontamination Facility. . . . . . . . . . . . . . . . . . . 16

11 Capsule Holder (Anode Assembly) for the Remote Capsule Decontamination Facility . . . . . . . . . . . . . . 17

12 Metal Removal Rate as a Function of Position for a Hastelloy C-276 Capsule Electropolished in 75\% Phosphoric Acid at $46^{\circ} \mathrm{C}$ and a Current Density of $21.5 \mathrm{~A} / \mathrm{dm}^{2}$. . . . . . . . 20 


\section{ELECTROCHEMICAL DECONTAMINATION OF STRONTIUM \\ FLUORIDE STORAGE CAPSULES}

\section{INTRODUCTION}

Electropolishing, as the name implies, is an electrochemical process that has been used extensively for both laboratory and industrial-type applications to produce a smooth, polished surface on a variety of metals and alloys. The basic theory of electropolishing as applied to electrochemical decontamination is illustrated in Figures 1 and 2 . The object to be decontaminated serves as the anode in an electrolytic cell. The passage of a high-density electric current results in the anodic dissolution of the surface metal and the establishment of a concentration gradient at the anode surface (Figure 1). The presence of this gradient leads to a difference in current density for the microscopic "peaks" and "valleys" on the surface, and results in a preferential dissolution of the surface irregularities and a progressive smoothing of the surface as depicted in Figure 2.

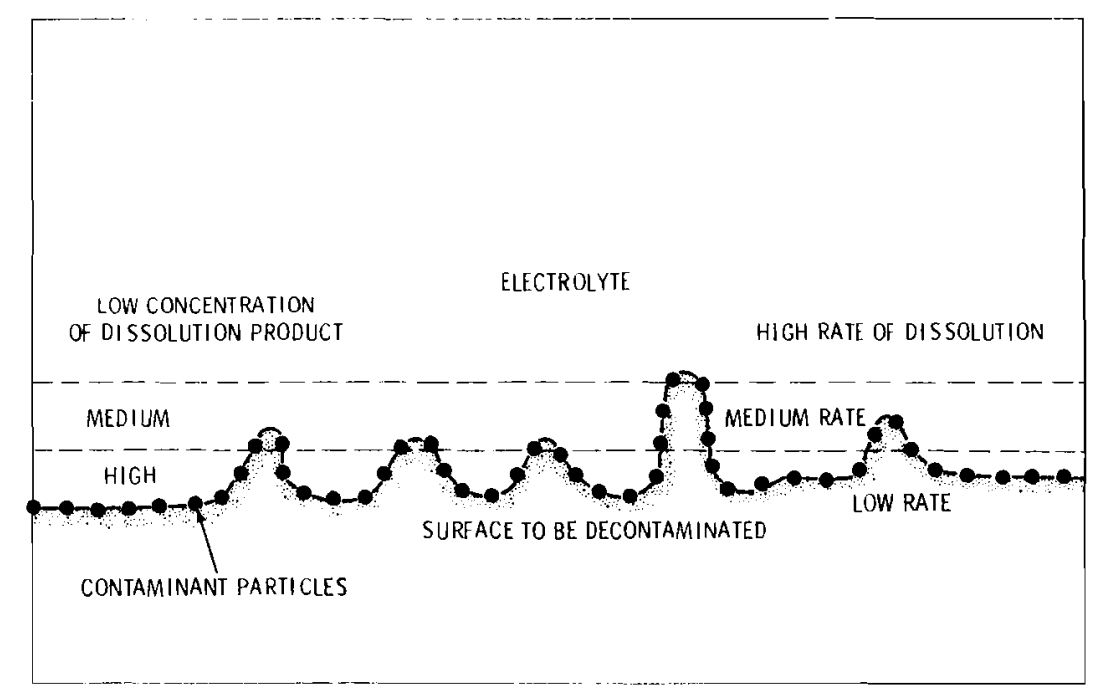

FIGURE 1. Theory of Electrochemical Decontamination. Anodic dissolution of the surface releases entrapped radioactive contamination into the electrolyte. The variation in dissolution rate with reaction product concentration results in the preferential solution of surface irregularities and a progressive smoothing of the surface. 


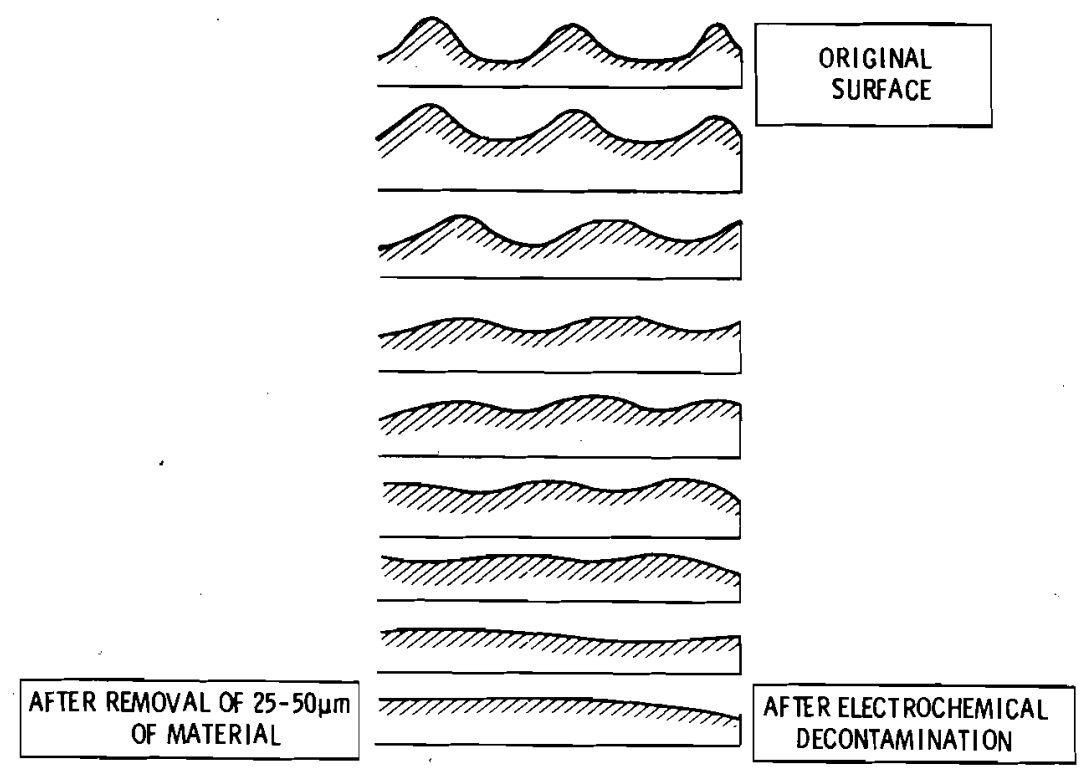

FIGURE 2. Surface Smoothing as a Function of Metal Removal for Electropolished Material

Any radioactive contamination that is present either on the surface or entrapped within scratches and other surface imperfections is removed and released into the electrolyte by the surface dissolution process. Recontamination from the electropolishing solution is minimized by the diluent effect of the electrolyte and by the concurrent elimination of the surface imperfections; thus, a simple water rinse after electropolishing is usually sufficient to remove the residual electrolyte and leave a contaminationfree surface.

The utilization of electrochemical decontamination techniques for a particular alloy and component geometry requires the selection of a suitable electrolyte and a determination of the optimum operating parameters for the metal-electrolyte system. The process variables include current density and electrode potential, temperature and degree of agitation of the electrolyte, and the geometry and spacing of the electrodes. Figure 3, for example, shows a representative current density versus cell voltage curve for electrolytes based on phosphoric acid and illustrates the optimum current density 


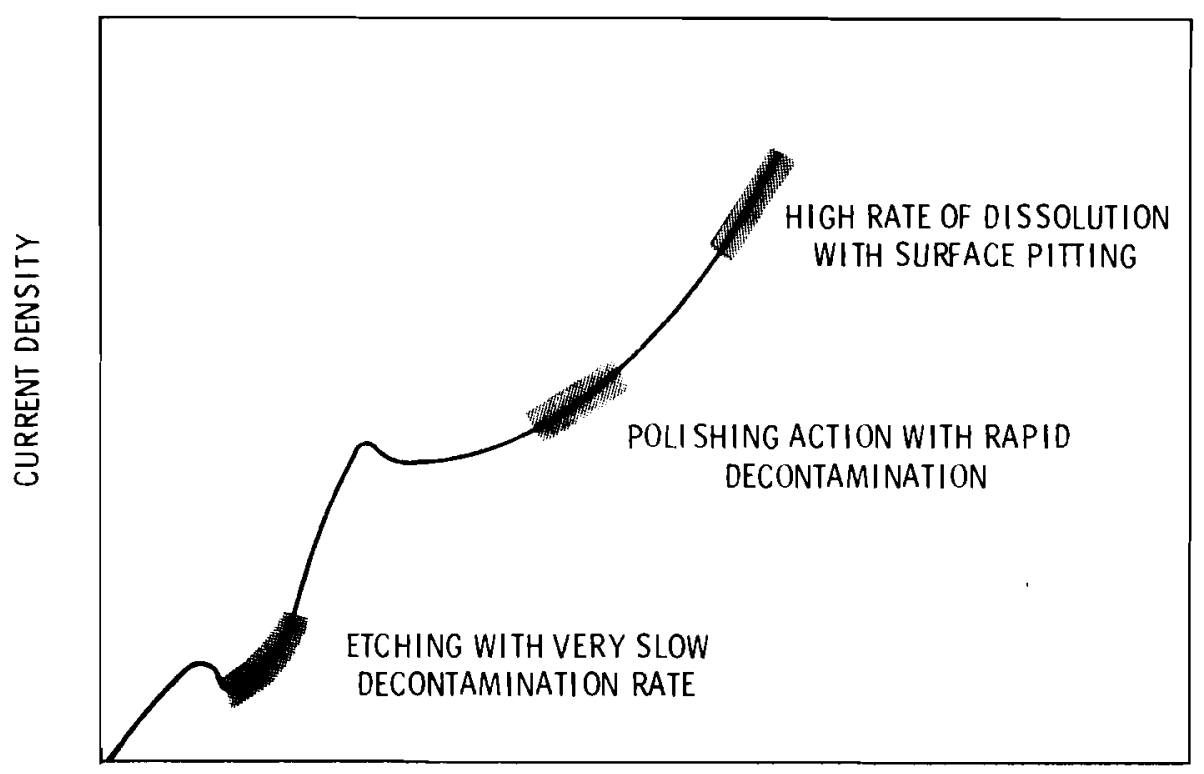

CELL VOLTAGE

FIGURE 3. Relationship of Current Density and Cell Voltage for Electropolishing Showing the Optimum Operating Region for Electrochemical Decontamination

region for electropolishing and electrochemical decontamination. At low voltages and current densities the dissolution rate is very low and grain boundaries are preferentially attacked, resulting in etching of the surface rather than polishing. At very high current densities, dissolution is rapid and is accompanied by excessive oxygen evolution resulting in severe pitting of the surface.

Careful control of the process variables is essential for commercial electropolishing operations where the major objective is an improvement in the appearance and reflectivity of the metal surface. The control requirements for electropolishing used as a decontamination technique are less stringent. Considerations other than surface finish may be more important, such as extending solution life to minimize the volume of secondary waste produced or selecting a specific electrolyte to facilitate disposal of the spent solution. However, a good surface finish is helpful for 
laboratory ware and other applications where recontamination is probable because it facilitates subsequent decontamination using conventional techniques.

Most of the electrochemical decontamination studies conducted under this and other programs have utilized electrolytes based on phosphoric acid. The advantages of this type of electrolyte include stability, safety, and applicability to a number of alloy systems with only minor adjustments in electrolyte composition. Other acids and chemicals can be added as required to enhance surface passivity, increase brightness, or promote sludging. Representative operating conditions for decontamination using electrolytes based on phosphoric acid are solution temperatures of 40 to $80^{\circ} \mathrm{C}$, phosphoric acid concentrations of 40 to $80 \%$, and current densities of 5 to $40 \mathrm{~A} / \mathrm{dm}^{2}$. Typical decontamination times range from 5 to $30 \mathrm{~min}$, corresponding to the removal of approximately 8 to $50 \mu \mathrm{m}$ of surface material at a current density of $19 \mathrm{~A} / \mathrm{dm}^{2}$.

The basic type of electrolytic cell used for electrochemical decontamination is illustrated in Figure 4. The electropolishing tank and cathodes are usually stainless steel to minimize chemical attack by the electrolyte. In addition, the buildup of contamination on the tank and cathode surfaces can be prevented by periodically reversing the polarity of the electrolytic cell and electropolishing these surfaces. The cathodes need to be properly shaped and positioned to ensure uniform polishing of the part to be decontaminated if maintenance of tolerances is important.

\section{CAPSULE DECONTAMINATION STUDIES}

The decontamination studies described in this report were initiated in July, 1975 at the suggestion of D. W. Jeppson of ARHCO to explore the potential of electropolishing as a decontamination technique for strontium fluoride storage capsules. Several preliminary decontamination tests were conducted using representative contaminated sections cut from Hastelloy C-276 cylinders and a phosphoric-sulfuric acid electrolyte. These ring sections were all successfully decontaminated by the electropolishing treatment. 


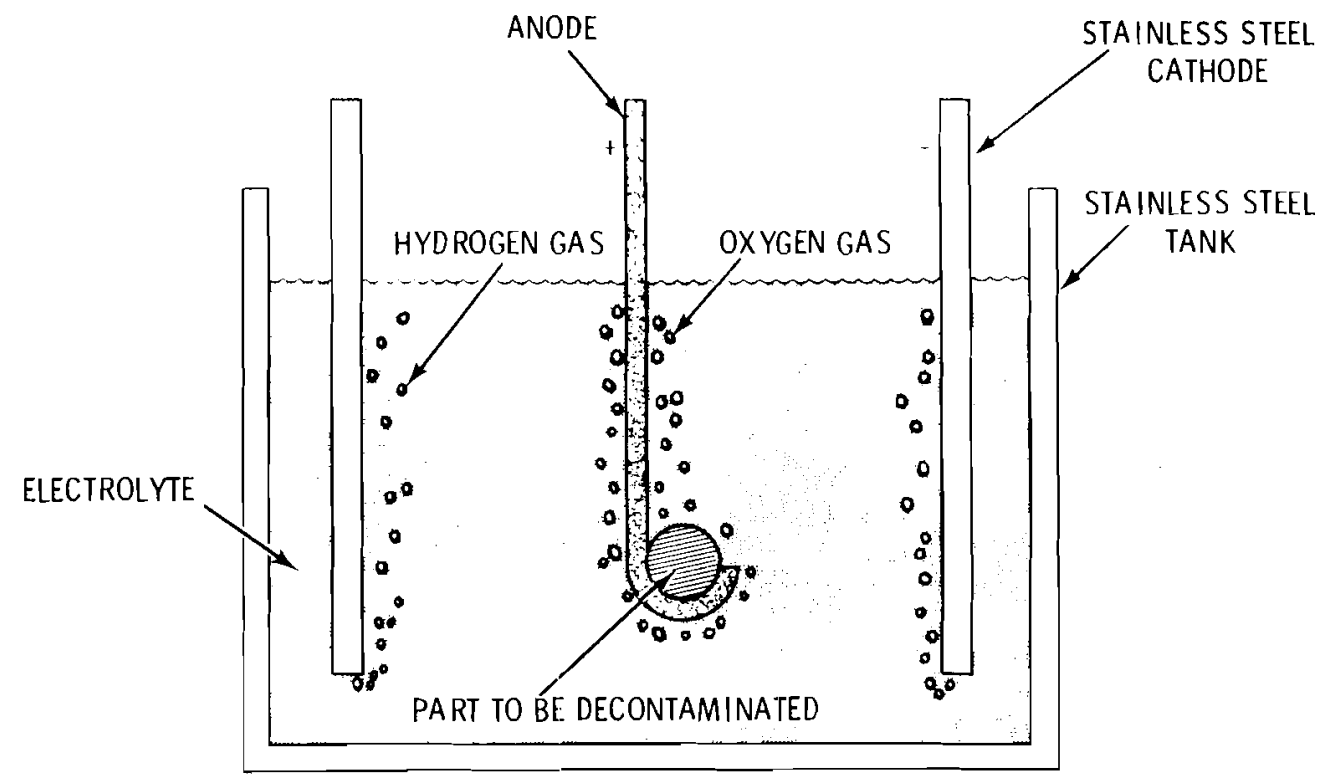

FIGURE 4. Schematic Drawing of Electrolytic Cell used for Electrochemical Decontamination. Other system components include a dc power supply and provision for heating and agitating the electrolyte.

Larger-scale experiments were undertaken using empty capsules that had been contaminated by processing through the regular hot cell welding and handling procedures. The electrolyte employed in these later tests was 75\% phosphoric acid with no sulfuric. This change in electrolyte composition was made to ensure compatibility of the electrolyte with the available B-plant liquid waste disposal facilities. The first capsule tested was decontaminated in a short time period except for the in-cell weld zone. The radiation level of this weld area could not be reduced to nonsmearable even by prolonged electropolishing at high current densities. This was due to contamination incorporated in the weld metal by the capsule sealing operation. Changes were subsequently made in the in-cell loading procedure to minimize entrapment of contamination in the weld.

The second test capsule processed with the improved in-cell handing procedure was completely decontaminated as illustrated in Table 1. Based 


\section{TABLE 1. Capsule Decontamination as a Function}

of Electropolishing Time

\begin{tabular}{ccccc}
$\begin{array}{c}\text { Cell } \\
\text { Voltage, V }\end{array}$ & $\begin{array}{c}\text { Current } \\
\text { Density, } \mathrm{A} / \mathrm{dm}^{2}\end{array}$ & $\begin{array}{c}\text { Total } \\
\text { Time, min }\end{array}$ & $\begin{array}{c}\text { Smearable } \\
\text { Contamination }\end{array}$ \\
\cline { 5 - 6 } & & & 0 & $4 \mathrm{rad} / \mathrm{hr}$ \\
9 & 14.5 & & 6 & $400 \mathrm{mrad} / \mathrm{hr}$ \\
9 & 14.5 & 13 & $1000 \mathrm{counts} / \mathrm{min}$ \\
9.5 & 18.1 & 26 & $<200$ counts $/ \mathrm{min}$
\end{tabular}

on the results of these capsule decontamination studies, it should be possible to use electropolishing on a routine basis to produce nonsmearable capsule surfaces in less than 30 min with less than $50 \mu \mathrm{m}$ of metal removal.

\section{OPERATING PARAMETER STUDIES}

Surfaces can be decontaminated using electrolyte compositions and cell operating conditions that would not be considered optimum for industrial surface finishing operations. In the present application, a straight phosphoric acid electrolyte was selected for evaluation rather than the more complex electrolytes usually used to electropolish nickel and nickelbase alloys because of concern over possible electrolyte disposal problems.

A series of laboratory tests were conducted to determine the optimum operating ranges for temperature, acid concentration, and dissolved metal content for the electroplishing of Hastelloy C-276. The specific effects of these three parameters on limiting current density and current density versus cell voltage relationships are summarized in Figures 5 through 7 .

The anode current density versus cel1 voltage curve for Hastelloy C-276 in $55 \%$ phosphoric acid at $25^{\circ} \mathrm{C}$ (Figure 5 ) showed a very distinct plateau region corresponding to a limiting current density of $11.7 \mathrm{~A} / \mathrm{dm}^{2}$. At $75^{\circ} \mathrm{C}$, the shape of the curve was essentially the same, but the limiting current density was more than twice as high $\left(28.7 \mathrm{~A} / \mathrm{dm}^{2}\right)$, and the plateau region was shifted to a higher cell voltage range. Increasing the acid concentration 


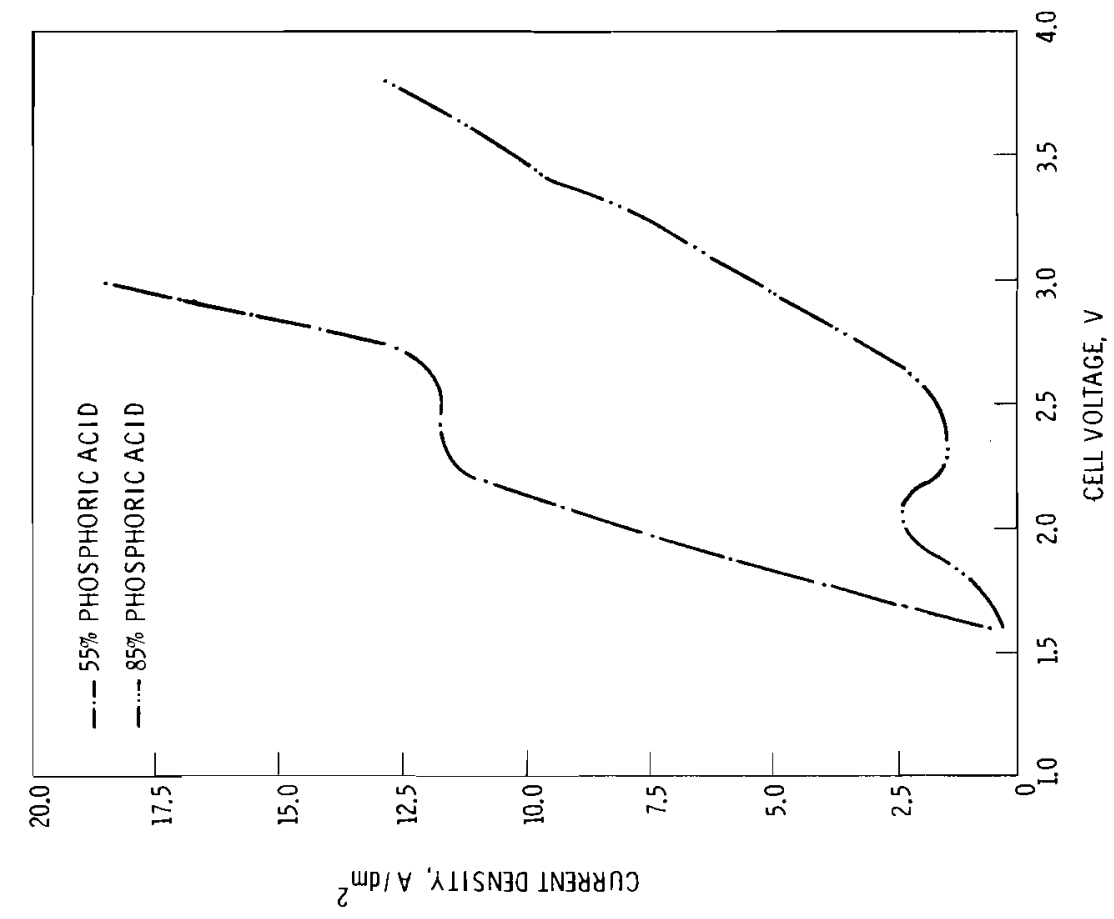

ธ

도웜

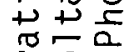

웅

D

$y=6$

웡

ن

स्ते

잉

$+>$

过

는

4 更

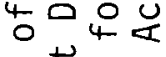

岛它出.

\& $\leq$

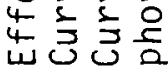

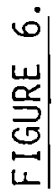

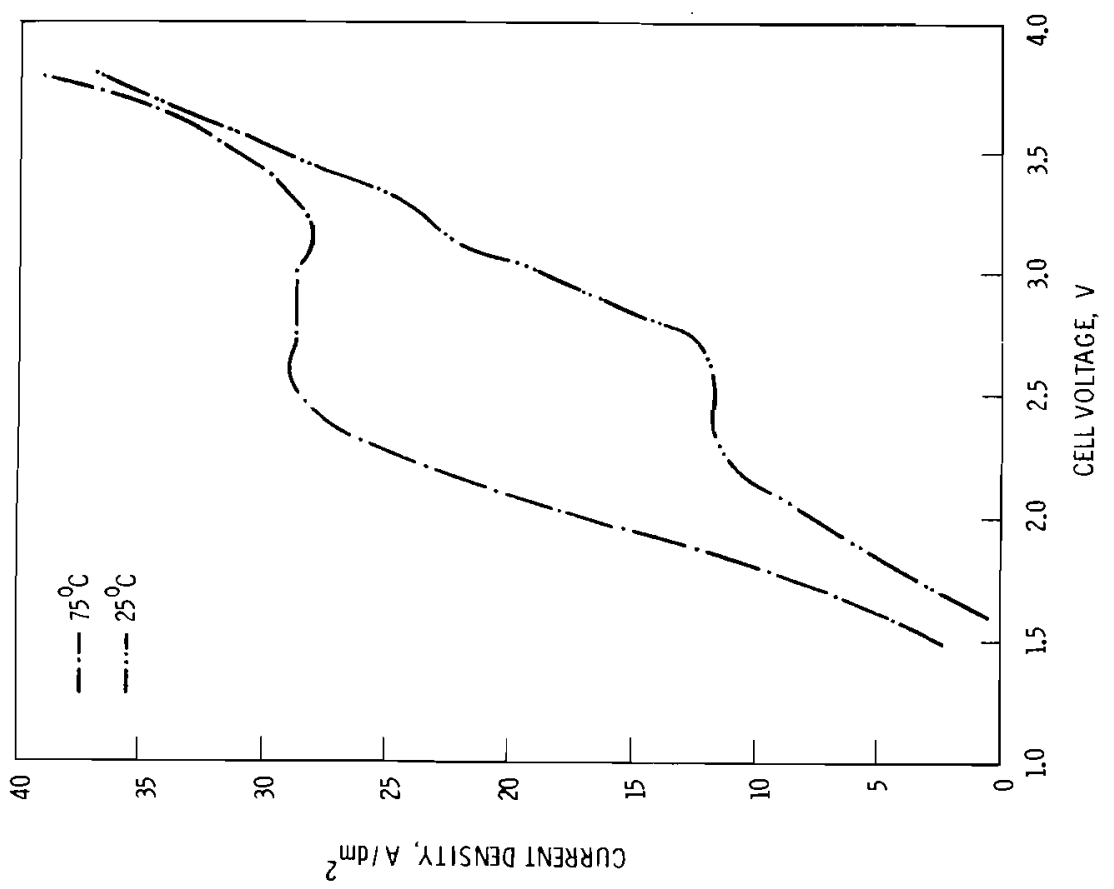

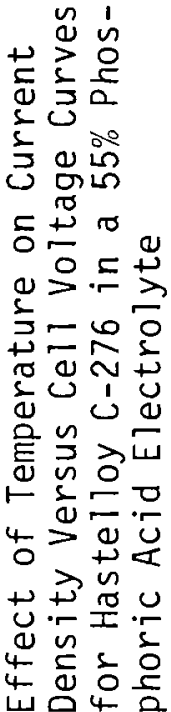

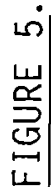




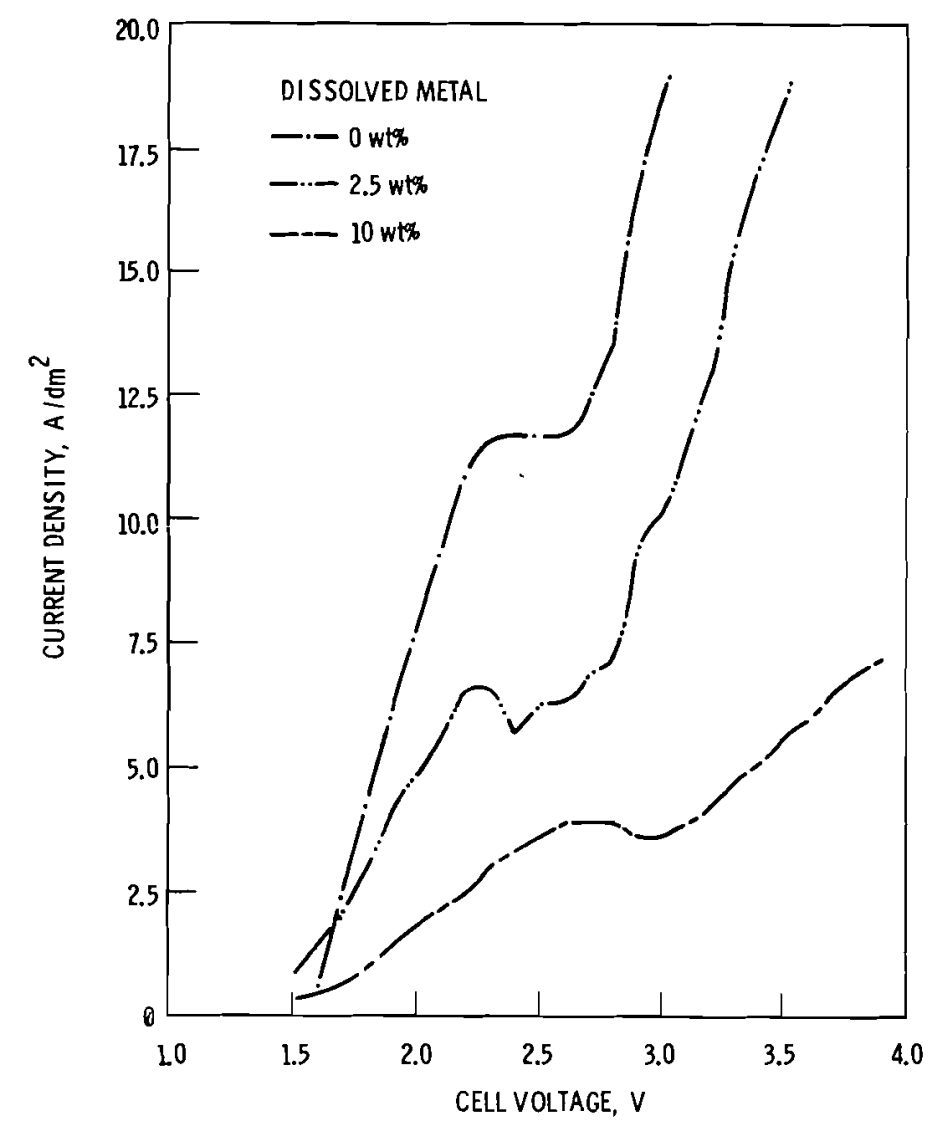

FIGURE 7. Effect of Dissolved Metal Content on Current Density Versus Cell Voltage Curves for Hastelloy $\mathrm{C}-276$ in $55 \%$ Phosphoric Acid at $25^{\circ} \mathrm{C}$

from $55 \%$ to $85 \%$ (Figure 6 ) resulted in a substantial decrease in the 1 imiting current density at $25^{\circ} \mathrm{C}$ from $11.7 \mathrm{~A} / \mathrm{dm}^{2}$ to 1 ess than $2 \mathrm{~A} / \mathrm{dm}^{2}$. The plateau region remained at about the same cell voltage range, but was poorly defined. Increasing the dissolved metal content of the electrolyte (Figure 7) also decreased the limiting current density from 11.7 to $26.5 \mathrm{~A} / \mathrm{dm}^{2}$ for $2.5 \mathrm{wt} \%$ dissolved metal and to $\sim 3.5 \mathrm{~A} / \mathrm{dm}^{2}$ for $10 \mathrm{wt} \%$ dissolved metal. The plateau region also shifted to a higher cell voltage range and became less distinct at the highest dissolved metal content. 
These test results show that the limiting current density for the electropolishing of Hastelloy C-276 in phosphoric acid increases significantly with increasing temperature and decreases both with increasing acid concentration and dissolved metal content. Conversely, profile tests using the capsule electropolishing facility showed that metal removal was more uniform at lower temperatures and higher acid concentrations. The effect of current density on the quality of electropolish obtained using the capsule facility also was investigated for Hastelloy C-276 and 316-L stainless steel capsules (Figure 8). Good polishes were obtained for current densities greater than approximately $16 \mathrm{~A} / \mathrm{dm}^{2}$, with etching occurring as expected at lower current densities. The absence of a well defined plateau in the current-voltage curves for the capsules (Figure 8 ) is attributed to end effects for the cylindrical electrode arrangement of the capsule facility.

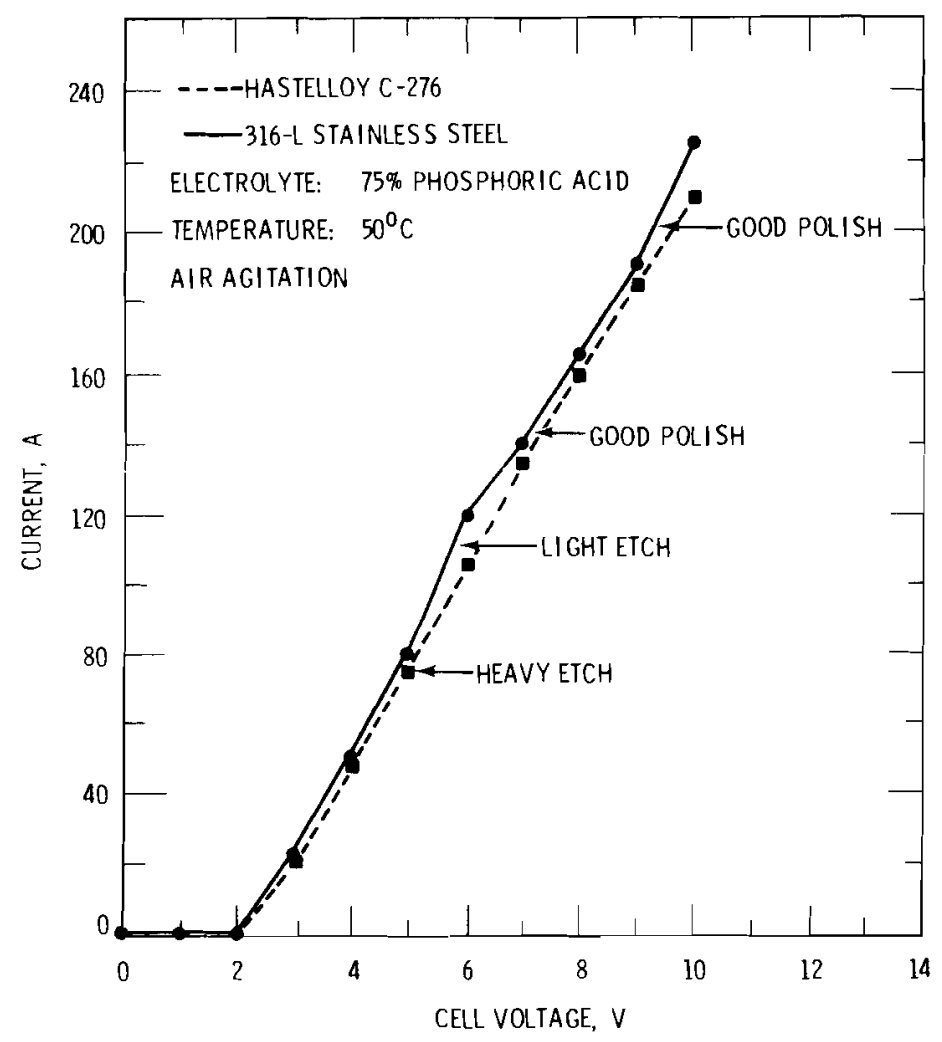

FIGURE 8. Current Versus Cell Voltage Curves for Hastelloy C-276 and 316-L Stainless Steel Capsules Electropolished in the Capsule Decontamination Facility 
Based on these test results, the recommended electrolyte composition and operating parameters for the capsule electropolishing facility are:

Electrolyte - 75\% Phosphoric Acid

Temperature $\quad-45$ to $55^{\circ} \mathrm{C}$

Current Density- 17 to $21 \mathrm{~A} / \mathrm{dm}^{2}$

These operating conditions represent a compromise with respect to metal removal rate, surface finish, and uniformity of metal removal. The recommended current density range corresponds to a current of $\sim 175 \pm 15 \mathrm{~A}$. Some adjustment in this value may be necessary to compensate for the decrease in limiting current density for the capsules with the buildup of dissolved metal in the electrolyte.

\section{SOLUTION LIFE STUDIES}

The electrolyte used for electropolishing or electrochemical decontamination does not have an infinite life. Only a certain amount of metal can be removed per liter of electrolyte consumed or requiring disposal. Some of the electrolyte (termed "dragout") is carried out of the electropolishing bath into the rinse cycle on the surface of the object being decontaminated. In commercial electropolishing operations this consumes about $0.4 \ell$ of electrolyte per square meter of surface area processed. Bath performance also may be limited by the buildup in the electrolyte of the metal dissolved by the electropolishing process. The amount of dissolved metal that can be tolerated and still permit satisfactory operation is a function of the electrolyte used and the particular metals involved, but normally is on the order of $6 \mathrm{wt} \%$ dissolved metal. In some metal-electrolyte systems the metal removed from the anode by the electropolishing process plates out on the cathode. In other systems, the metal is removed from solution by the precipitation of insoluble metal salts (sludging). If dragout, plating, and/or sludging are not sufficient to keep the dissolved metal content 
within the desired limits, a calculated portion of the bath can be removed and replaced with fresh solution on a regular basis. In the case of electrochemical decontamination, the effective solution life also may be limited by the buildup of contamination in the electrolyte to a level where recontamination from the bath becomes a problem.

A series of solution life tests were conducted for Hastelloy C-276 in $55 \%$ phosphoric acid to determine the disposition of the metal removed from the anode; i.e., does the metal stay in solution, plate out on the cathode, or form sludge? Strontium fluoride powder was added periodically to the surface of the anode during electropolishing to simulate contamination removal. The amount of metal removed was determined as a function of integrated current, and the electrolyte and cathode surfaces were analyzed using $X$-ray fluoresence techniques at anode weight changes corresponding to $2.5,6$, and $10 \mathrm{wt} \%$ of the electropolishing solution.

The metal removal rate for these tests was $0.75 \mathrm{~g} / \mathrm{A}-\mathrm{hr}$. This corresponds to a surface thickness change of $7.75 \mu \mathrm{m} / \mathrm{A}-\mathrm{hr} / \mathrm{dm}^{2}$. Essentially all of the metal removed from the anode went into solution at the 2.5 and $6 \mathrm{wt} \%$ dissolved metal levels. There was no sludge formation as evidenced by filtration tests of the electrolyte using whatman No. 5 filter paper. The cathode surface was darkened, however, indicating the onset of plating. This initial deposit was primarily nickel, but had a significantly higher iron and cobalt content than the Hastelloy $\mathrm{C}-276$. (a) With additional electropolishing, the amount of metal plating out on the cathode increased to approximately 10\% of the amount of metal removed between the 6 and $10 \mathrm{wt} \%$ dissolved metal levels. The deposit was still predominantly nickel with

(a) The nominal composition of Hastelloy $\mathrm{C}-276$ in wt\% is:

$\begin{array}{lrlrl}\text { Mo } & 16.0 & \text { W } & 3.8 & \text { Ni balance }(\sim 65.7) \\ \mathrm{Cr} & 15.5 & \mathrm{Co} & <2.5 \\ \mathrm{Fe} & 5.5 & \mathrm{Mn} & <1.0\end{array}$


relatively high concentrations of iron and cobalt and less than nominal amounts of tungsten and molybdenum. There still was no sludge formation at $10 \mathrm{wt} \%$ dissolved metal, and 211 of the chromium and strontium remained in solution.

These results show that control of the dissolved metal content for this electropolishing system is by a plating rather than a sludging mechanism. This means that it may be necessary to periodically reverse the current to remove the deposited material from the cathode. Calculations based on these test data show that it should be possible to process in excess of forty capsules using a $20-\ell$ electrolytic cell and stay within a $6 \mathrm{wt} \%$ dissolved metal content. The limiting factor with respect to solution life will probably be contamination buildup, since these tests also show that the strontium remains in solution.

\section{SPECTRAL EMITTANCE STUDIES}

One possible disadvantage of electropolishing as a decontamination technique for fission product storage capsules would be the production of a low emittance surface that would seriously impair the heat transfer characteristics of the capsules. A study was conducted to compare the spectral emittance in the infrared region $(\lambda=1.6$ to $2.7 \mu \mathrm{m})$ of as-received Hastelloy C-276 tubing with the emittance of various types of "bright" and "du11" surface finishes prepared by electropolishing Hastelloy C-276 ring specimens. The spectrical emittance measurements were made by L. R. Bunnell using the following technique and procedure:

"The principle behind the measurements is the fact that a heated object radiates energy in the infrared which is detected by an infrared pyrometer as power. If a pyrometer is calibrated with a blackbody $(E=1)$, the emittance of another object is $E=\frac{S_{\text {Object }}}{S_{\text {blackbody }}}$ where $S$ is the signal received by the pyrometer. The $S_{\text {blackbody }}$ is known from an internal thermocouple (calibrated chrome 1-a lume 1). 
Initially, the tubing was provided with end caps and placed in a furnace, with a thermocouple on the inside wall of the tubing directly opposite the site viewed by the pyrometer. This arrangement resulted in a substantial reflection off the furnace element and consequent spurious signals. To eliminate this problem, the sample and end cap assembly was placed on a high-powered ( $\sim 2 \mathrm{~kW}$ ) hot plate, and baked-out Fiberfrax insulation was placed around the sides and over the top. The pyrometer, an Infrared Industries Thermodot TD-6B, generated a signal which was recorded by one pen of a Hewlett-Packard two-pen recorder, Model 17501A. The thermocouple output was recorded by the second pen. Data were taken on both heating and cooling cycles, and in one case, a sample was left at $500^{\circ} \mathrm{C}$ for $16 \mathrm{hr}$ to determine possible surface aging effects."

The results of the spectral emittance studies are summarized in Table 2.

TABLE 2. Spectral Emittance as a Function of Surface Condition

\begin{tabular}{lc} 
Surface Condition & Spectral Emittance, E \\
\cline { 1 - 2 } As-received & $0.22 \pm 0.06$ \\
Mat Finish & $0.26 \pm 0.03$ \\
Dull Finish & $0.19 \pm 0.04$ \\
Bright Finish No. 1 & $0.24 \pm 0.01$ \\
Bright Finish No. 2 & $0.23 \pm 0.01$ \\
Bright Finish No. 3 & $0.20 \pm 0.03$
\end{tabular}

The emittance values represent the average of at least five measurements made between 300 and $500^{\circ} \mathrm{C}$. These data show that there is no significant difference between the spectral emittance characteristics of as-received Hastelloy C-276 tubing and specimens electropolished under various conditions 
to produce dull and bright finishes. These studies also demonstrated that there was no appreciable oxide formation and thus no significant change in emittance for specimens exposed to air for $16 \mathrm{hr}$ at $500^{\circ} \mathrm{C}$ or for $1 \mathrm{hr}$ at $600^{\circ} \mathrm{C}$.

\section{CAPSIILE DECONTAMINATION FACILITY}

Electropolishing is ideal for the remote decontamination of parts with regular geometries because it is an electrochemical rather than a mechanical decontamination process. The only mechanical component required for an electropolishing facility is a pump to agitate the electrolyte and even the pump can replaced by air agitation if filtration of the electrolyte is not required.

The electropolishing facility designed for the in-cell decontamination of fission product storage capsules is shown in Figure 9. The major components are:

- the electrolytic tank,

- the electrolyte heating and cooling system,

- the air sparger system,

- the cathode, and

- the capsule holder.

The electrolytic tank (Figure 9) has a 20- $\ell$ capacity and is fabricated from AISI 304-L stainless steel. The combination steam heating and water cooling coils attached to the outer surface of the tank are required to heat the electrolyte to the initial operating temperature and then to dissipate the combined heat output of the strontium fluoride $(\sim 1 \mathrm{~kW})$ and the electropolishing process $(21.5 \mathrm{~kW})$. During operation, the temperature of the electrolyte is maintained within the desired 45 to $55^{\circ} \mathrm{C}$ range by adjusting the flow of cooling water from outside the hot cell. An air sparger inside the cathode is used to agitate the electrolyte to promote heat transfer and to prevent the formation of gas channels on the capsule surface by dispersing the oxygen bubbles formed on the anode. 


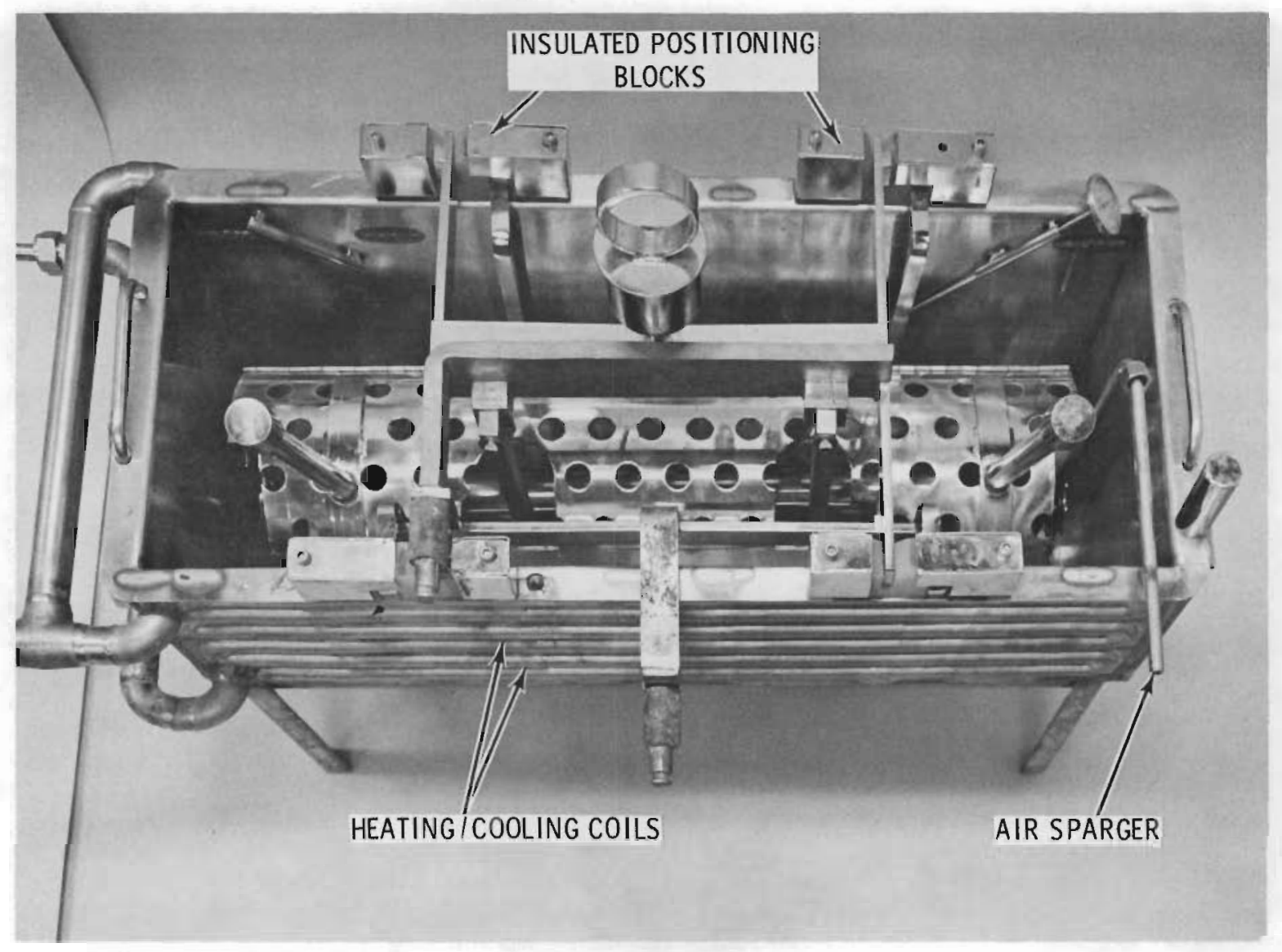

FIGURE 9. Electropolishing Cell Designed for the Remote Decontamination of Fission Product Storage Capsules

The perforated cylinder shown in Figure 10 is the cathode. It opens as illustrated to facilitate remote insertion of the capsule. The cathode is fabricated from AISI 304-L stainless steel and is cylindrical to maintain a constant anode-to-cathode distance. This provides a constant current density along the capsule surface and thus promotes uniform metal removal as required to maintain the dimensional tolerances of the capsule. 


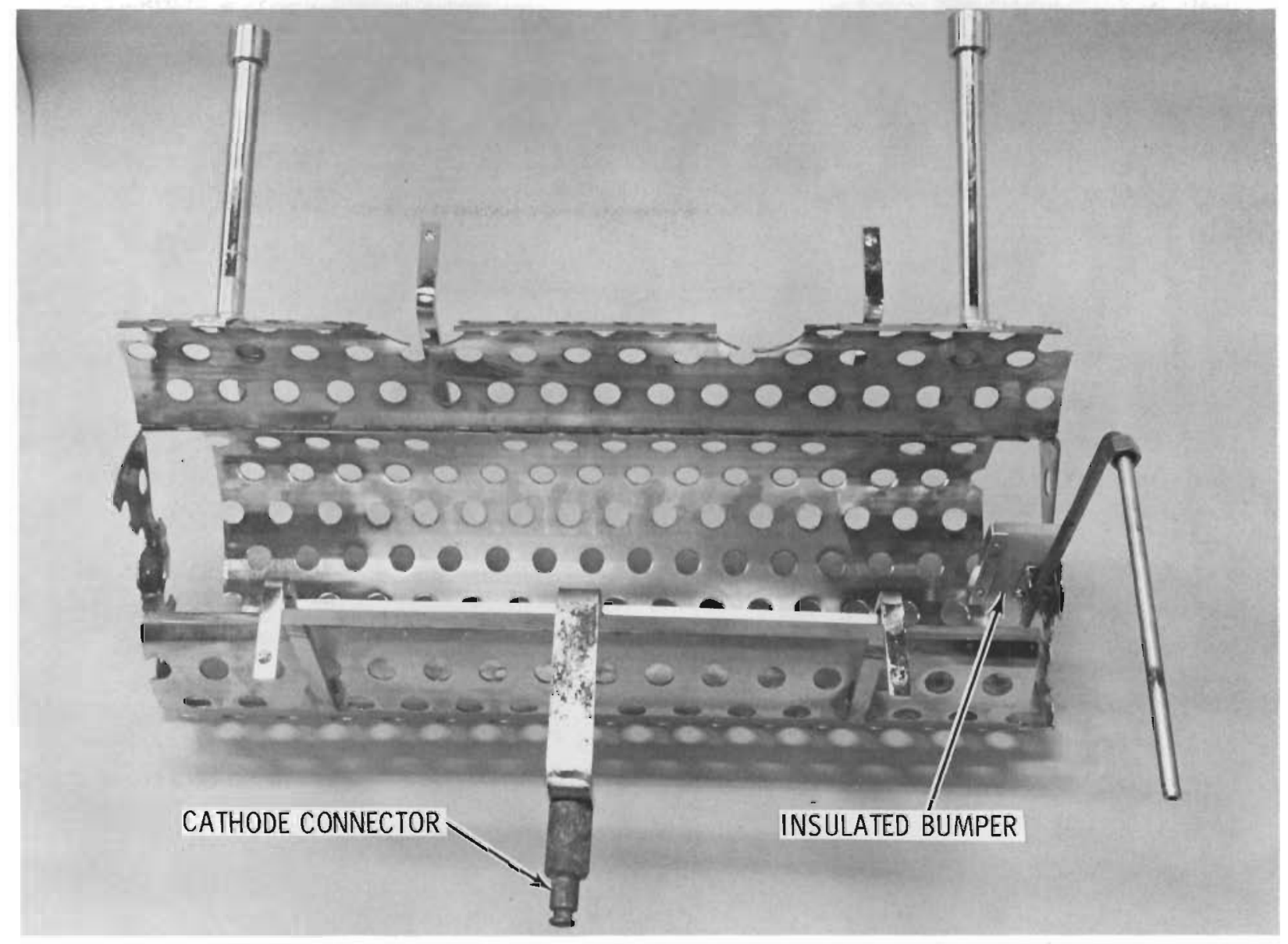

FIGURE 10. Cathode Assembly for the Remote Capsule Decontamination Facility

The capsule holder shown in Figure 11 supports and positions the capsule and also serves as the anode contact. Direct current flows through the copper bus bar, down the titanium support structure, and into the capsule through the tantalum spring contacts. Titanium and tantalum are used for the support and contact materials because of their low erosion rate under normal electropolishing conditions. This is due to the formation of a thin, insulating surface oxide film that inhibits anodic dissolution. However, this film is easily disrupted by the racking operation to provide an 


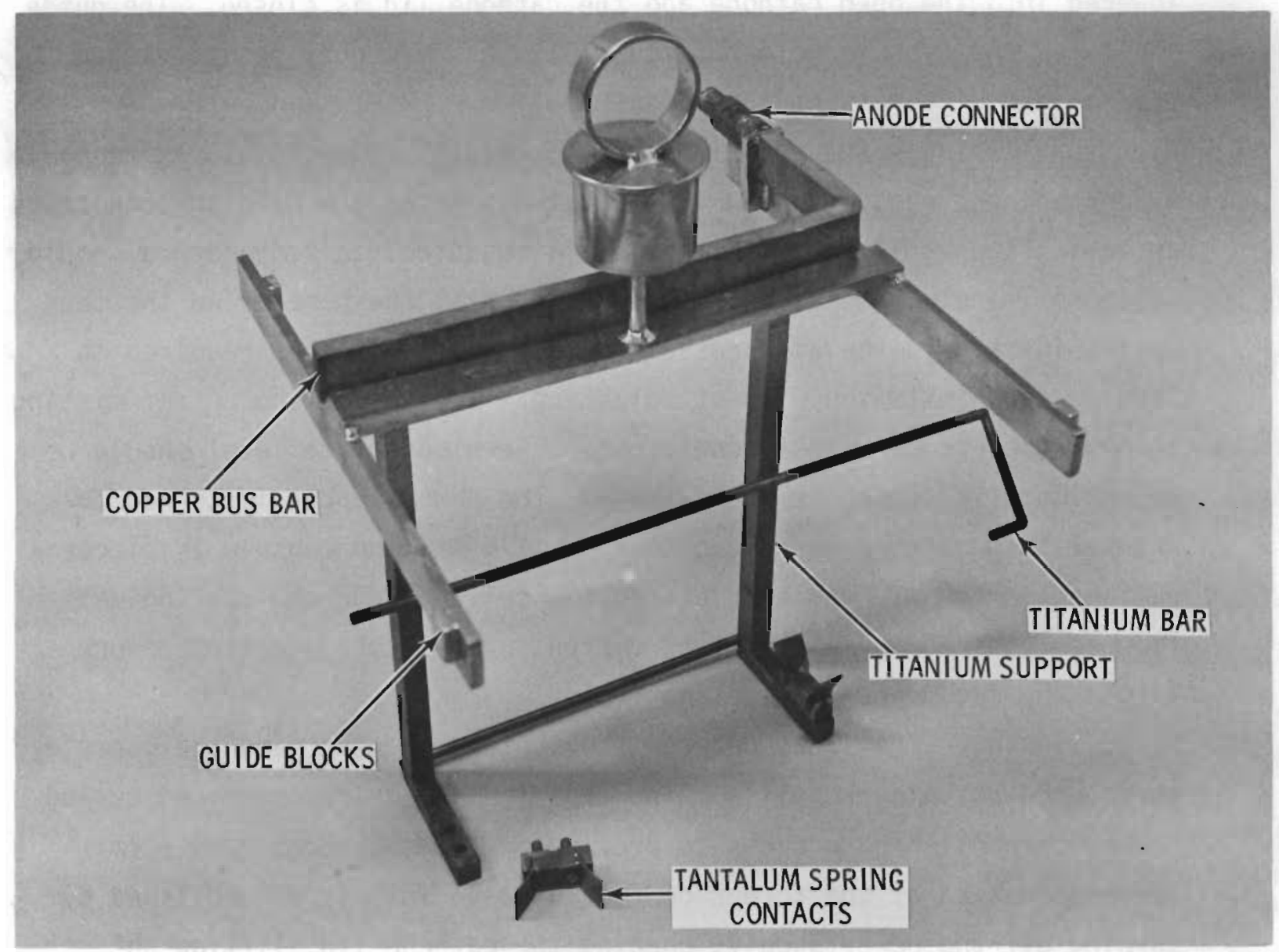

FIGURE 11. Capsule Holder (Anode Assembly) for the
Remote Capsule Decontamination Facility

electrical contact that can accommodate high current densities without arcing. The contacts can be replaced if required by substituting a new set of contact blocks as illustrated in Figure 11.

The use of the electropolishing facility for the decontamination of fission product storage capsules involves the following sequential operations:

1) Loading - The contaminated capsule is placed on the tantalum contacts and positioned so that the end of the capsule is approximately 2 to $5 \mathrm{~cm}$ from the titanium bar (Figure 11). The capsule holder is then 
lowered into the open cathode and the cathode lid is closed. The guide blocks on the capsule holder (Figure 11) insure proper positioning of the capsule with respect to the cathode.

2) Electropolishing - The positive current lead is connected to the capsule holder and the negative lead to the cathode using the welding connectors shown in Figures 10 and 11 . The initial electrolyte temperature should be approximately $45^{\circ} \mathrm{C}$ as indicated by the dial thermometer on the tank wall (Figure 9). The air pressure should be adjusted as required to provide good agitation without splashing. Tests have shown that misting is negligible under these conditions. The electrolyte level should be approximately $3 \mathrm{~cm}$ above the cathode. The power supply is turned on and set to provide a current output of $2175 \mathrm{~A}$. The capsule is electropolished for 12 min while adjusting the cell voltage and cooling water flow as required to maintain the current and electrolyte temperature within the recommended operating limits.

3) Repositioning - The areas between the tantalum contact and the capsule surface do not electropolish. The capsule must be repositioned during the electropolishing process to provide new contact areas and permit decontamination of the former contact areas. This is accomplished by turning off the power supply, opening the cathode lid, lifting the capsule holder a few centimeters, and then pushing the capsule forward against the titanium bar (Figure 11) using the insulated bumper at the rear of the cathode assembly (Figure 10).

4) Rinsing - After electropolishing for an additional $12 \mathrm{~min}$, the capsule holder with the capsule is removed, thoroughly rinsed using cold, noncontaminated water, and then allowed to air dry.

5) Unloading - After monitoring and release, the decontaminated capsule is transported to the west side of the hot cell in the capsule holder and pushed directly into the clean outer capsule.

The capsule decontamination facility will required periodic decontamination to prevent prolonged buildup of contamination and plated material on the tank walls and cathode. This can be accomplished electrochemically 
by 1) reversing the current leads to make the normal cathode an anode and using a dummy capsule as the cathode and 2) using the normal cathode with the tank as the anode. These decontamination operations will require approximately 5 min of electropolishing at $175 \mathrm{~A}$ and should be followed by disposal of the contaminated electrolyte, rinsing of the tank, and refilling with fresh electrolyte.

\section{CAPSULE PROFILE STUDIES}

The amount of metal removed from the capsule by the decontamination process can be controlled by proper selection of current density and electropolishing time. At $19 \mathrm{~A} / \mathrm{dm}^{2}(175 \mathrm{~A})$, for example, the metal removal rate for Hastelloy $\mathrm{C}-276$ capsules is $1.65 \mu \mathrm{m} / \mathrm{min}$, corresponding to a total metal removal of $40 \mu \mathrm{m}$ for the 24 -min decontamination treatment. This metal must be removed uniformly, however, to maintain the dimensional tolerances of the capsule. This requires proper design and placement of the cathode and anode holder and control of the operating parameters including electrolyte composition, temperature, and current density.

The capsule decontamination facility was designed with a cylindrical cathode (Figure 10) to promote uniform metal removal around the circumference of the capsule. The more difficult problem was to attain uniform metal removal along the length of the capsule. The initial capsule profile tests showed that the metal removal rate was significantly higher at the capsule ends due to the larger effective cathode area and lower near the anode holder due to shadowing. These problems were minimized by redesigning the anode holder and reducing the cathode area at the ends of the cathode. Uniformity of metal removal also was improved by operating at higher acid concentrations and lower temperatures.

The resulting capsule profile is shown in Figure 12 for a Hastelloy $\mathrm{C}-276$ capsule electropolished in $75 \%$ phosphoric acid at $46^{\circ} \mathrm{C}$. The average metal removal rate was $1.88 \mu \mathrm{m} / \mathrm{min}$ at a current density of $21.5 \mathrm{~A} / \mathrm{dm}^{2}$. The 


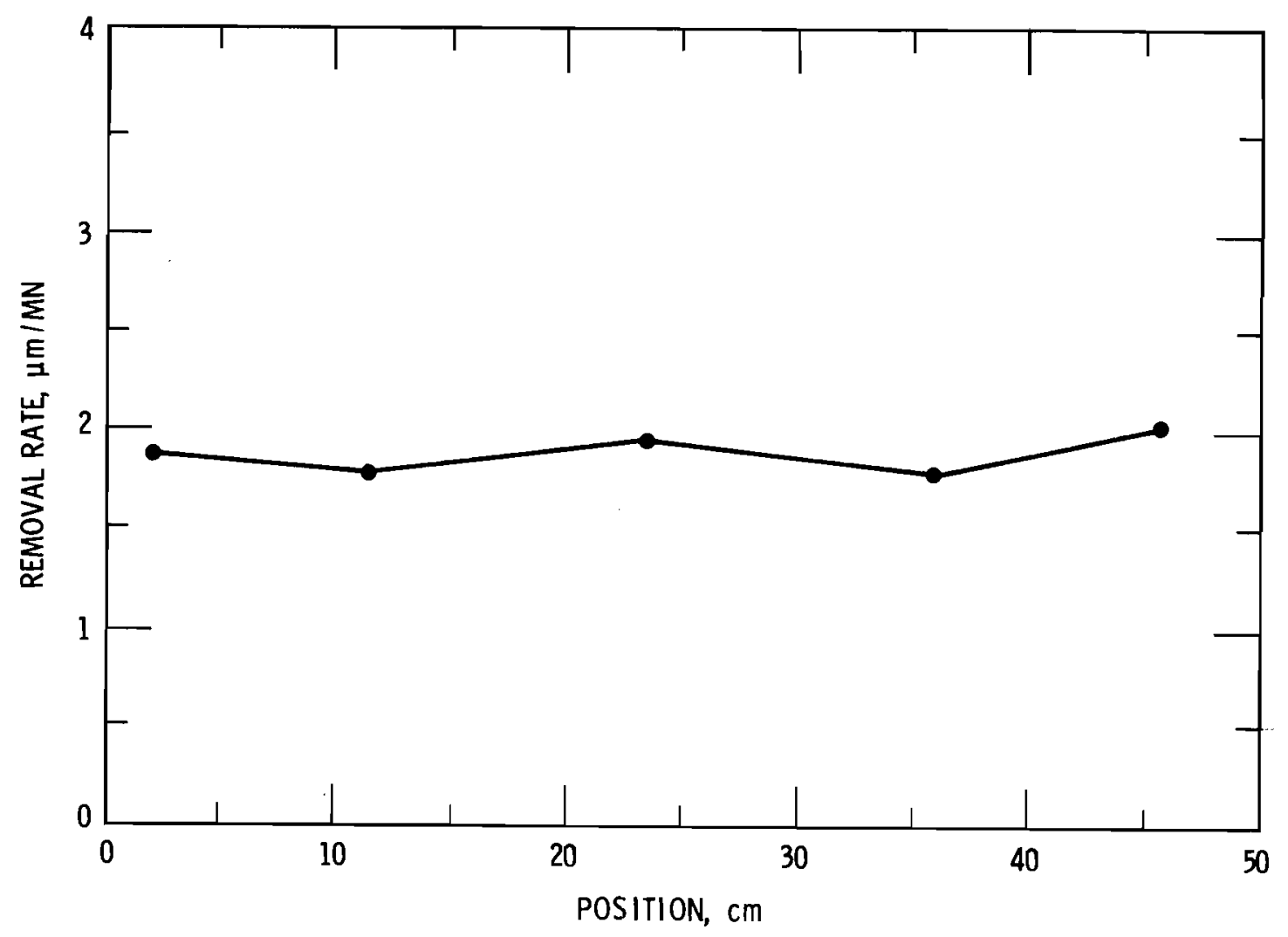

FIGURE 12. Metal Removal Rate as a Function of Position for a Hastelloy C-276 Capsule Electropolished in $75 \%$ Phosphoric Acid at $46^{\circ} \mathrm{C}$ and a Current Density of $21.5 \mathrm{~A} / \mathrm{dm}^{2}$

standard deviation for the five measurement positions along the capsule was on $1 y 0.11 \mu \mathrm{m} / \mathrm{min}$, or less than $6 \%$ of the mean. This corresponds to a difference of less than $5 \mu \mathrm{m}$ in the amount of metal removed at any two points along the capsule for a decontamination treatment removing an average of $40 \mu \mathrm{m}$ from the capsule surface.

\section{SAFETY CONS.IDERATIONS}

Electropolishing is a comparatively safe industrial process. The low voltages used for electropolishing $(<12 \mathrm{~V}, \mathrm{dc})$ preclude any significant electrical shock hazard. Remote operation of the capsule decontamination 
facility effectively eliminates any personnel hazard due to electrical arcing, contact with the electrolyte, or inhalation of acid fumes. The only remaining potential safety hazard is the hydrogen generated electrolytically at the cathode. The maximum rate of hydrogen generation is $0.4 \mathrm{l} / \mathrm{A}-\mathrm{hr}$, or less than $1.2 \mathrm{l} / \mathrm{min}$ for the recommended capsule decontamination facility operating conditions. This amount of hydrogen is negligible compared with either the hot cell air sweep rate $(>7,000 \mathrm{l} / \mathrm{min})$ or the volume of air in the hot cel1 $(20,000 \ell)$.

\section{ACKNOWLEDGMENTS}

Appreciation is extended to the Atlantic Richfield Hanford Company for support of this work and to the associates of D. W. Jeppson at ARHCO for helpful suggestions and assistance in the design of the remote capsule decontamination facility. The authors also wish to thank Dr. R. D. Nelson of PNL for his encouragement of this work and S. M. Faber, H. E. Kjarmo, and W. R. Boyer of PNL for assistance with the experimental studies and fabrication of the capsule facility. 
.

$\because$ 
BNWL -2125

UC -70

\section{DISTRIBUTION}

NO. OF

COPIES

OFFSITE

1

ERDA Chicago Patent Group

U.S. Energy and Research Development Administration Argonne, IL 60439

A. A. Churm

2

U.S. ERDA Headquarters Washington, DC 20545

R. W. Ramsey

R. A. Wolfe

1

ERDA Savannah River Operations Office

P. 0. Box A

Aiken, SC 29810

W. J. Brumley

27

ERDA Technical Information Center

$1 \quad$ Argonne National Laboratory

9700 South Cass Avenue

Argonne, IL 60439

W. J. Tyrrell

2

E. I. duPont de Nemours and Company

Savannah River Laboratory

Aiken, SC 29801

M. D. Boersma

P. H. Permar

1

E. I. duPont de Nemours and Company

Savannah River Plant

Aiken, SC 29801

A. S. Messick

ONSITE

ERDA Richland Operations Office
R. A. Anderson
R. B. Goranson
J. L. Rhoades 


\section{DISTRIBUTION (contd)}

NO. OF

COPIES

21

Atlantic Richfield Hanford Company
H. Babad
G. A. Beitel
L. I. Brecke
D. A. Bruce
R. E. Felt
R. C. Forsman
A. R. Hawkins
D. W. Jeppson (5)
E. J. Kosiancic
D. N. Morril
R. C. Roa 1
H. P. Shaw
A. Smith
R. W. Spencer
F. R. Wilbanks
R. A. Yoder
R. A. Zins $1 \mathrm{i}$

1

United Nuclear Industries

T. M. Hall

22

Battelle, Pacific Northwest Laboratories

R. P. Allen (5)

H. W. Arrowsmith (10)

L. R. Bunnel1

J. H. Jarrett

R. P. Marsha 11

R. D. Nelson

A. M. Platt

Technical Information (2) 